\title{
SPATIAL VARIABILITY OF MECHANICAL RESISTANCE TO PENETRATION EVALUATED WITH MOBILE UNIT ON HAPLIC VERTISOL CULTIVATED WITH MANGO
}

\author{
JORGE W. CORTEZ ${ }^{1}$, HÉLIO L. LOPES ${ }^{2}$, DANIELA S. COELHO ${ }^{3}$, \\ SÁLVIO N. S. ARCOVERDE ${ }^{4}$
}

\begin{abstract}
Since the advent of mechanized farming and intensive use of agricultural machinery and implements on the properties, the soil began to receive greater load of machinery traffic, which can cause increased soil compaction. The aim of this study was to evaluate the spatial variability of soil mechanical resistance to penetration (RP) in the layers of 0.00-0.10, 0.10-0.20, 0.20-0.30 and $0.30-0.40 \mathrm{~m}$, using geostatistics in an area cultivated with mango in Haplic Vertisol of the northeastern semi-arid, with mobile unit equipped with electronic penetrometer. The RP data was collected in 56 points from an area of $3 \mathrm{ha}$, and random soil samples were collected to determine the soil moisture and texture. For RP data analysis we used descriptive statistics and geostatistics. The soil mechanical resistance to penetration presented increased variability, with adjustment of the spherical and exponential semivariograms in the layers. We found that $42 \%$ of the area in the layer of 0.10-0.20m showed RP values above 2.70 MPa. Maximum values of RP were found in the layer of $0.19-0.27 \mathrm{~m}$, predominantly in $56 \%$ of the area.
\end{abstract}

KEYWORDS: soil compaction; machinery traffic; agricultural mechanization.

\section{VARIABILIDADE ESPACIAL DA RESISTÊNCIA MECÂNICA À PENETRAÇÃo AVALIADA COM UNIDADE MÓVEL EM VERTISSOLO HÁPLICO CULTIVADO COM MANGA}

RESUMO: Com o advento da mecanização agrícola e o uso intensivo de máquinas e implementos agrícolas nas propriedades, o solo passou a receber maior carga do tráfego de máquinas, o que pode causar aumento da compactação do solo. O objetivo do trabalho foi avaliar a variabilidade espacial da resistência mecânica do solo à penetração (RP), nas camadas de 0,00-0,10;0,10-0,20;0,20-0,30 e 0,30-0,40 m, por meio da geoestatística, em área cultivada com manga, em Vertissolo Háplico do semiárido nordestino, com unidade móvel equipada com penetrômetro eletrônico. A coleta de dados de RP foi realizada em 56 pontos de uma área de 3 ha, sendo tomadas também amostras aleatórias para a determinação da umidade e da textura do solo. Para a análise dos dados de RP, utilizou-se da estatística descritiva e da geoestatística. A resistência mecânica do solo à penetração apresentou variabilidade elevada, sendo ajustado o semivariograma esférico e exponencial nas camadas. Verificou-se que $42 \%$ da área na camada de 0,10-0,20 m apresentou valores de RP acima de 2,70 MPa. Foram encontrados valores máximos de RP, na camada de 0,19-0,27 m, predominante em $56 \%$ da área.

PALAVRAS-CHAVE: compactação do solo; tráfego de máquinas; mecanização agrícola.

\footnotetext{
${ }^{1}$ Engo . Agrônomo, Prof. Dr., Faculdade de Ciências Agrária, UFGD/Dourados - MS, Fone: (67)3410-2442, jorgecortez@ufgd.edu.br

${ }^{2}$ Engo . Agrônomo, Prof. M. Sc., Universidade Federal do Vale do São Francisco, UNIVASF/Petrolina-PE, helio.lopes@univasf.edu.br

${ }^{3}$ Enga . Agrícola e Ambiental, Universidade Federal Rural de Pernambuco, UFRPE/Recife - PE, daniela.coelho@hotmail.com.br

${ }^{4}$ Eng $^{\mathrm{o}}$. Agrícola e Ambiental, Mestre, Universidade Federal do Vale do São Francisco, UNIVASF/Petrolina - PE,

salviounivasf@hotmail.com

Recebido pelo Conselho Editorial em: 3-4-2013

Aprovado pelo Conselho Editorial em: 12-11-2013
} 


\section{INTRODUCTION}

The determination of soil mechanical resistance to penetration (RP) can be done using static, dynamometric or electronic penetrometers. The electronic penetrometers can be coupled to mobile sampling unit, like a system assembled on a quadricycle (AGUIAR et al., 2009), or be pulled and connected to the hydraulic system of a tractor (BONNIN et al., 2010). Penetrometers can also be used manually, being of springs (MEDEIROS et al., 2010), electronic (COELHO et al., 2012) or of impact.

As there is a correlation between compaction and RP (RIBON \& TAVARES FILHO, 2008), usually critical values are determined for the RP that mainly depend on the crop, soil, moisture and type of management of the area. So it has been attributed limiting values of RP for root growth of most cultivated species. SENE et al. (1985) assert that for clay soils values above $2.50 \mathrm{MPa}$ are considered restrictive to plant development, while for sandy soils, it is believed that the critical value for RP is between 6.00 and 7.00 MPa.

SECCO et al. (2009) observed, for example, that the maximum penetration resistance of 2.65 and 3.36 MPa in Latosol were restrictive for grain yield of wheat and maize, respectively, but there was no reduction in the production of soybeans when the maximum RP was 3.26 MPa. For crops such as beans, the RP in the range of 1.29 to $2.87 \mathrm{MPa}$ did not limit their productivity in a Red Latosol (CARVALHO et al., 2006).

MARTINS et al. (2010) when evaluating the compaction of a Red Yellow Latosol under vegetable coverage (coffee, mango and bare soil), found that in the layer of 0.00-0.20 and 0.20$0.40 \mathrm{~m}$ in coffee and mango crops differed from bare soil for RP, being the highest RP values in the layer of $0.20-0.40 \mathrm{~m}, 14.66,12.65$ and $10.37 \mathrm{MPa}$, for coffee, mango and bare soil, respectively, characterizing physical impediment for root development.

COELHO et al. (2012) found the RP by manual electronic penetrometer in a Haplic Vertisol cultivated with mango in the Brazilian northeastern semi-arid, and considering the specific maximum RP along the profile without performing the resistances averages in a depth range, they observed that more than $70 \%$ of the area has zones with RP above $2.0 \mathrm{MPa}$ and $4.4 \%$ of that same area reaches levels above $3.0 \mathrm{MPa}$ and the specific maximum resistances of about $75 \%$ is in the range of $0.30-0.35 \mathrm{~m}$.

The aim of this study was to evaluate the spatial variability of soil mechanical resistance to penetration in layers of $0.00-0.10,0.10-0.20,0.20-0.30$ and $0.30-0.40 \mathrm{~m}$, by geostatistics means, in area cultivated with mango for nine years, in Haplic Vertisol of the Brazilian northeastern semi-arid with mobile unit equipped with electronic penetrometer.

\section{MATERIAL AND METHODS}

The study was conducted in a batch of irrigated perimeter of Mandacaru, Juazeiro - state of Bahia (BA), in Brazil, which is located in UTM zone (timezone 24L), latitude of 8961020 to $8960820 \mathrm{~m}$ south, longitude of 345180 to $345380 \mathrm{~m}$ west, and average elevation of $345 \mathrm{~m}$. According to Köppen, the climate of the region is presented as tropical semi-arid, BshW type, characterized by the scarcity and irregularity of rainfall with summer rains and strong evaporation as a result of high temperatures, and flat terrain.

The soil in the area is classified as Haplic Vertisol, clay loam texture (Table 1), according to the Brazilian System of Soil Classification (EMBRAPA, 2006; COSTA et al., 2008). Deformed soil samples were taken at random points inside the area in layers of $0.00-0.10,0.10-0.20,0.20-0.30$ and $0.30-0.40 \mathrm{~m}$, with aid of an auger for determination of gravimetric moisture of the soil (EMBRAPA, 1997), and the average values within each layer are shown in Table 1. 
TABLE 1. Granulometric composition of Haplic Vertisol in area cultivated with mango (JuazeiroBA, Brazil, 2011).

\begin{tabular}{|c|c|c|c|c|}
\hline Layers & Clay & Sand & Silt & Moisture \\
\hline $\mathrm{m}$ & $-\overline{----}$ & $\mathrm{g} \mathrm{kg}^{-1}$ & ------- & $\%$ \\
\hline $0.00-0.10$ & 316 & 440 & 244 & 14.8 \\
\hline $0.10-0.20$ & 323 & 431 & 246 & 15.2 \\
\hline $0.20-0.30$ & 390 & 421 & 189 & 15.0 \\
\hline $0.30-0.40$ & 378 & 392 & 230 & 15.2 \\
\hline
\end{tabular}

The area in which this study was performed is cultivated with mango (Mangifera indica L. cv. Tommy), Tommy Atkins variety, 9 years old, who was deployed with conventional tillage, using a spacing of $8 \mathrm{~m} \times 8 \mathrm{~m}$, totaling 468 plants distributed in 3 ha. The crop treatments in the area consisted of mechanized application of fungicides, insecticides and foliar fertilizers and fruit harvest with animal traction. The spacing of the crop was maintained with weeds throughout the year with mechanized cutting being performed when necessary. Irrigation of the culture was performed by surface with furrows in the projection of the tree crown.

The equipment used for RP data collection were a Honda Fourtrax ATV - Trx420TM and an electronic penetrometer PenetroLOG ${ }^{\circledR}$ PLG1020 - Electronic Meter of Soil Compaction, of the Falker Agricultural Automation company. The meter follows the recommendations of international standard ASAE S.313.3 (ASAE, 1999), which specifies the rules and procedures for the measurement of soil compaction (FALKER, 2010). For the use of the penetrometer in vehicles such as ATV, the complete system is called SoloStar (FALKER, 2008), which is an automatic system for data collection. To determine the coordinates of the point of collection we used a differential global positioning system.

The methodology used for spatial distribution of soil mechanical resistance to penetration consisted of assembly the regular mesh of collection of $50 \times 50 \mathrm{~m}$ in the projection of the tree crown (3m away from the planting row). In order to verify the spatial variability among the sampling mesh points in the area, it was created micromesh within the mesh of $50 \times 50 \mathrm{~m}$, where data were collected every $10 \mathrm{~m}$ toward the front and side of the topographic profile, and all the data were collected on the same day. The data were collected at 56 points of the area, recording values of RP with electronic penetrometer every centimeter of depth up to $0.40 \mathrm{~m}$. Subsequently, the data were organized by layer $(0.00-0.10,0.10-0.20,0.20-0.30$ and $0.30-0.40 \mathrm{~m})$ calculating the average of the $\mathrm{RP}$ in the range of depth, as well as the maximum RP values (specific) were selected at each point in the 0.00-0.40cm (RPmax) layer, and the depths where RPmax (RPMax Depth ) occurred.

In the data analysis of RP, descriptive statistics and geostatistics were applied. The descriptive statistics allowed for exploratory data analysis of RP, obtaining the minimum, average and maximum values, standard deviation, variance, asymmetry and kurtosis. With geostatistics we constructed experimental and theoretical semivariograms with the respective adjustments parameters [nugget effect $\left(C_{0}\right)$, level $\left(C_{0}+C\right)$ and scope $(a)$ ]. In the adjustment of the semivariogram we observed the highest value of coefficient of determination $\left(\mathrm{R}^{2}\right)$, the lowest value of the sum of squares of deviations (RSS) and greater value of evaluation of spatial dependence (ESD). The semivariogram shows pure nugget effect when the semivariance is equal for all values of distance between points $(h)$. As $h$ increases, the semivariance also increases to a maximum value at which stabilizes. The analysis of spatial dependence (ESD) was performed according to the methodology described by LANDIM (1998), in weak <25\%, moderate between 25 and 75\%, and strong $>75 \%$, respectively. Following the modeling of semivariograms, a cross-validation was performed to verify the adjustment quality of the semivariogram, and later the interpolation by ordinary kriging to estimate values at not sampled locations and preparation of contour maps. 


\section{RESULTS AND DISCUSSION}

The evaluation of soil mechanical resistance to penetration (RP) by means of descriptive analysis showed increased averages as they deepen the layers, at the same time there is a reduction in the variation along the same (Table 2). The layer of $0.00-0.10 \mathrm{~m}$ presents lower RP in relation to the underlying layers, which may be attributed to the deposition of organic matter, contributing to the reduction of soil density in this region of the soil. Moreover, we observed that the values of the RP layers $0.10-0.20 \mathrm{~m}, 0.20-0.30 \mathrm{~m}$ and $0.30-0.40 \mathrm{~m}$ were higher than $2.0 \mathrm{MPa}$, reaching specific values higher than 6.5 MPa at certain depths (Table 2). COELHO et al. (2012) found lower values of RP in area cultivated with mango for 15 years, in Haplic Vertisol, with moisture values similar to this study, indicating that the occurrence of RP is due to the management used and not to the time of cultivation in the area, confirmed also by ROBOREDO et al. (2010) for Red Latosol.

TABLE 2. Descriptive statistics applied to data of soil mechanical resistance to penetration (MPa) in the evaluated layers (Juazeiro-BA, Brazil, 2011).

\begin{tabular}{|c|c|c|c|c|c|c|c|c|}
\hline Layers & Averages & $\mathrm{SD}^{1}$ & Variance & Minimum & Maximum & $\mathrm{CV}^{2}$ & Asymmetry & Kurtosis \\
\hline $\mathrm{m}$ & \multicolumn{2}{|c|}{-----MPa----- } & & \multicolumn{2}{|c|}{-----MPa----- } & $--\%--$ & & \\
\hline $0.00-0.10$ & 1.19 & 0.79 & 626565.6 & 0.20 & 3.09 & 66.1 & 0.94 & -0.19 \\
\hline $0.10-0.20$ & 2.34 & 1.33 & 1781008.7 & 0.84 & 5.09 & 57.1 & 0.71 & -0.92 \\
\hline $0.20-0.30$ & 2.38 & 1.00 & 1001640.9 & 1.21 & 4.62 & 42.0 & 0.86 & -0.29 \\
\hline $0.30-0.40$ & 2.64 & 0.97 & 933434.0 & 1.35 & 4.74 & 36.5 & 0.71 & -0.64 \\
\hline \multirow[t]{2}{*}{ RPMax } & 3.89 & 1.57 & 2465098.5 & 1.48 & 6.77 & 40.3 & 0.29 & -1.19 \\
\hline & \multicolumn{2}{|c|}{----- m ----- } & & \multicolumn{2}{|c|}{----- m ----- } & $\%$ & & \\
\hline RPMax Depth & 0.28 & 0.11 & 114.8 & 0.09 & 0.40 & 37.8 & -0.29 & -1.43 \\
\hline
\end{tabular}

${ }^{1}$ Standard deviation; ${ }^{2}$ Coefficient of variation.

Using the classification proposed by WARRICK \& NIELSEN (1980), in relation to the coefficient of variation (CV) of the evaluated soil layers, only layer of $0.00-0.10 \mathrm{~m}$ showed high CV ( $\mathrm{CV}>62 \%)$, and the others showed CV considered medium $(12 \%<\mathrm{CV}<62 \%)$. The greater coefficient of variation in the surface layer $(0.00-0.10 \mathrm{~m})$ is due, probably, its exposure to weather, to the direct contact with traffic of carts, trampling of animals and several mechanized operations of management of the area.

Considering the characteristics of the variable under study, atypical values could not be ignored as reported by SILVEIRA et al. (2010), as these represent the observed reality in the field, where the compression can be presented in a specific manner and with considerable variability over the area and depths evaluated. Therefore, with the use of a geostatistical analysis these inconsistent values should be confronted with its neighbors in order to check whether there is the need to exclude them, as performed by CARVALHO et al. (2008).

The asymmetry of the RP data distribution was by the Pearson coefficient (As), (Table 2), showing that RP values in all layers presented an asymmetric distribution ( $\mid$ Asymmetry $\mid>0.15$ ). This fact was also observed by SILVEIRA et al. (2010) and MION et al. (2012) that evaluated the RP in Yellow Argisol, and concluded that the values of asymmetry and kurtosis suggest abnormal distribution, which was confirmed by the Shapiro-Wilks test (MION et al., 2012). The coefficient of kurtosis (k) is an important parameter of assessment in which we can observe the degree of flattening of the distribution, that is, how much a frequency curve will be flat in relation to a normal reference curve. In this case, all distributions showed coefficient of kurtosis $k<2.63$, which classifies them as leptokurtic or elongated, i.e., data show less variation and more pronounced modal frequency.

In the analysis of the semivariogram to RP, and in the first three evaluated layers the adjusted model was the spherical, while in the layer of $0.30-0.40 \mathrm{~m}$, the maximum resistances (RPmax) and the depth of occurrence of maximum resistances (RPMax Depth ) the adjusted model was the exponential. With exception of the layers $0.10-0.20 \mathrm{~m}$ and $0.30-0.40 \mathrm{~m}$, the other layers presented coefficients of determination $\left(\mathrm{R}^{2}\right)$ close to or equal to 1.0 (Table 3 ). 
TABLE 3. Data of semivariogram for soil mechanical resistance to penetration in the evaluated layers (Juazeiro-BA, Brazil, 2011).

\begin{tabular}{lcrrrrrrrc}
\hline \multicolumn{1}{c}{ Layers } & Model & $(\mathrm{Co})$ & $(\mathrm{C})$ & $\left(\mathrm{C}_{1}\right)$ & \multicolumn{1}{c}{$(\mathrm{a})$} & $\mathrm{R}^{2}$ & $\mathrm{RSS}$ & $\mathrm{ESD}$ & $\mathrm{CL}$ \\
\hline$---\mathrm{m}----$ & & & & & $--\mathrm{m}--$ & & & & \\
$0.00-0.10$ & Spherical & 0.2060 & 0.6768 & 0.4708 & 22.8 & 1.00 & 4.6 & 70 & $\mathrm{M}$ \\
$0.10-0.20$ & Spherical & 0.4080 & 1.7430 & 1.3350 & 23.2 & 0.74 & 11000 & 77 & $\mathrm{~S}$ \\
$0.20-0.30$ & Spherical & 0.2670 & 1.0390 & 0.7720 & 23.2 & 0.99 & 15.0 & 74 & $\mathrm{M}$ \\
$0.30-0.40$ & Expon. & 0.2760 & 0.9383 & 0.6623 & 6.9 & 0.67 & 1800 & 71 & $\mathrm{M}$ \\
RPMax & Expon. & 0.6630 & 2.5840 & 1.9210 & 17.3 & 0.99 & 1500 & 78 & $\mathrm{~S}$ \\
RPMax Depth & Expon. & 79.2 & 195.6 & 116.4 & 232.8 & 0.98 & 33.5 & 59 & $\mathrm{M}$ \\
\hline
\end{tabular}

$($ RPMax) = maximum resistances; $($ RPMax Depth ) = occurance depths of maximum resistances; (Co) = Nugget effect; $(\mathrm{C})$ = Level; $\left(\mathrm{C}_{1}\right)=$ Contribution; $(\mathrm{a})=$ Range; $\mathrm{R}^{2}=$ coefficient of determination; $\mathrm{RSS}=$ sum of the deviation squares; $\mathrm{ESD}=$ spatial dependence evaluator; $\mathrm{CL}=$ class $(\mathrm{M}-$ moderate and $\mathrm{S}-$ strong$)$.

The obtained ranges were 22.8, 23.2, 23.2 and 6.9m, respectively, for the layers of 0.00 $0.10 \mathrm{~m}, 0.10-0.20 \mathrm{~m}, 0.20-0.30 \mathrm{~m}$ and $0.30-0.40 \mathrm{~m}$. To RPMax and RPMax Depth the reaches were respectively 17.3 and $232.8 \mathrm{~m}$. COELHO et al. (2012) found ranges of 154.6, 108.3, 58.6 and $43.6 \mathrm{~m}$, respectively, for the layers of $0.00-0.10,0.10-0.20,0.20-0,30$ and $0.30-0.40 \mathrm{~m}$ of depth, greater than in this study, because it is an area with more crop lengh, indicating that in the course of time diminishes the spatial variability, and the RP tends to be more uniform in the area. CARVALHO et al. (2008) showed ranges of 23.03, 36.80 and $12.10 \mathrm{~m}$, respectively, for the same layers previously mentioned, in a study conducted in a 4.0 ha plot with sugarcane in a clayish Red Latosol using mesh of $20 \times 18.2 \mathrm{~m}$. We observed, therefore, that the effects on the range will depend on the handling of each type of soil, in addition to the amount and distribution of the samples in the field.

The contour maps estimated by ordinary kriging for soil mechanical resistance to penetration (Figures 1 and 2) are grouped into color classes of increasing order. From the maps obtained, it was possible to detect areas with uniform standards of RP, allowing the adoption of management measures more appropriate for each compaction level of the area, which would be impossible from a descriptive method analysis. It is possible to verify the presence of significant areas with RP above 2.0 MPa for all layers (Figures 1 and 2), especially at depths of $0.10-0.20 \mathrm{~m}, 0.20-0.30 \mathrm{~m}$ and $0.30-0,40 \mathrm{~m}$. The variation of RP between the layers and along the area can be related to the management performed in the area, to the movement of the machinery particularly during the harvest, to the accumulation of pressure in the soil, and to the natural accommodation processes of the particles. The accumulation of pressures in the soil occurs principally by animals, carts and machinery traffic, besides the absence of soil revolving for long periods and the natural accommodation of the particles (CARVALHO JÚNIOR et al., 1998). 

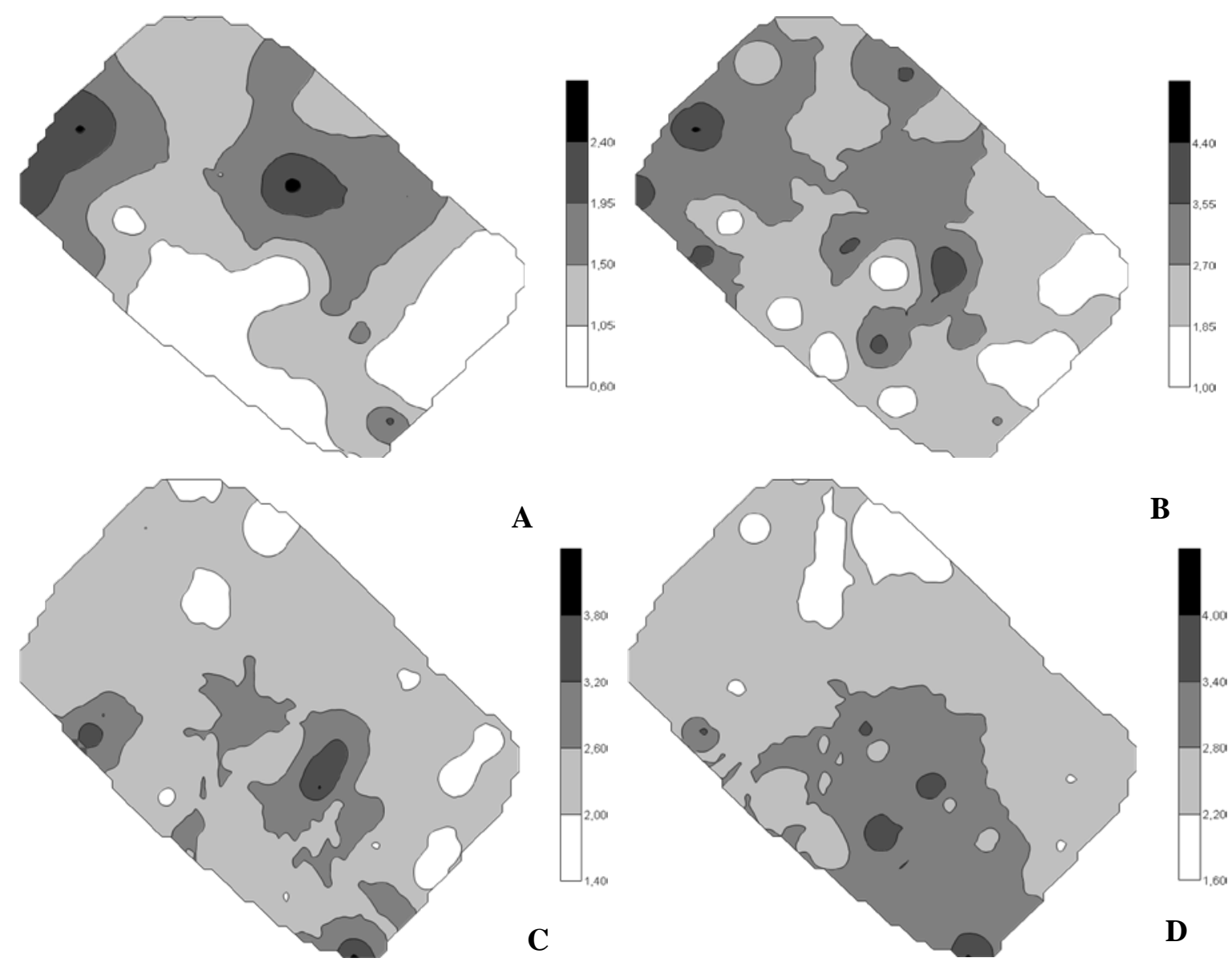

Figure 1. Maps of kriging for the soil mechanical resistance to penetration (MPa) in the evaluated layers: (A) $0.00-0.10 \mathrm{~m}$ and (B) $0.10-0.20 \mathrm{~m}$; (C) $0.20-0.30 \mathrm{~m}$ and (D) $0.30-0.40 \mathrm{~m}$ (Juazeiro-BA, Brazil, 2011).
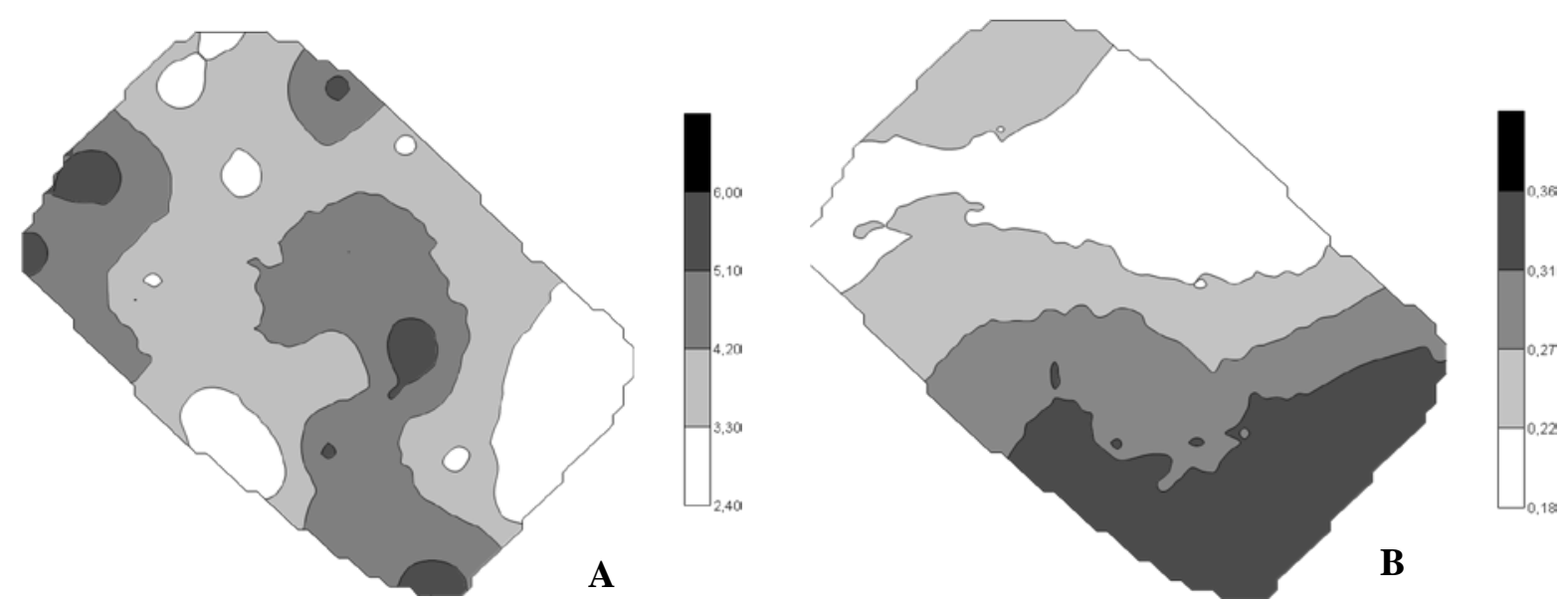

Figure 2. Maps of kriging for (A) RPMax (maximum resistances (MPa) in the evaluation point) and (B) RPMax Depth (depths of occurance of maximum resistances in meter-m), (JuazeiroBA, Brazil, 2011).

We verified that a little more than $42 \%$ of the area in depth of $0.10-0.20 \mathrm{~m}$ presented $\mathrm{RP}$ above 2.7 MPa (Figure 1 and Table 4). CUNHA et al. (2009) in the evaluation of different times that the tractor passes in a clayish Red Latosol, observed that the effect of tractor traffic was mainly concentrated in the surface layer $(0.00$ and $0.20 \mathrm{~m})$, supporting the data of this study wherein the machinery traffic caused the layer $0.10-0.20 \mathrm{~m}$ to receive most of the traffic load. The other layers also presented critical areas, but in a lesser extent. However, when considering the specific 
maximum resistances along the profile, that is, without performing the average of resistances in a depth range, we observed that the entire area shows RP above $2.4 \mathrm{MPa}$, and $38.2 \%$ of this same area reaches levels higher than 4.2 MPa and with possibility to reach 6.0 MPa. Furthermore, from the maximum specific resistances shown in Figure 1A, around $56 \%$ is in the range of 0.19 to $0.27 \mathrm{~m}$ (Figure 2B), but for COELHO et al. (2012), the specific maximum resistances are in the range of 0.30 to $0.35 \mathrm{~m}$ in area cultivated with mango, in Vertisol, in the same region, indicating that the occurrence of the maximum resistances is more superficial, probably because of the cultivation length of the area. We can infer that with time of use of the area the values of the depth of RPMax increase.

TABLE 4. Percentage of the area occupied by the different levels of compaction in the evaluated layers (Juazeiro-BA, Brazil, 2011).

\begin{tabular}{cccccc}
\hline \multirow{2}{*}{$\begin{array}{c}\text { Local/ } \\
\text { Layer }(\mathrm{m})\end{array}$} & \multicolumn{5}{c}{ Percentage of area (\%) } \\
\cline { 2 - 6 } & & & & \\
\hline $0.00-0.10$ & 26.40 & 38.10 & 28.00 & 7.30 & 0.20 \\
$0.10-0.20$ & 9.30 & 48.30 & 38.90 & 3.50 & 0.03 \\
$0.20-0.30$ & 5.70 & 77.00 & 15.30 & 1.90 & 0.02 \\
$0.30-0.40$ & 7.30 & 62.00 & 28.90 & 1.70 & 0.01 \\
RPMax $^{2}$ & 12.60 & 49.20 & 33.90 & 4.30 & 0.01 \\
RPMax Depth $^{3}$ & 28.40 & 27.92 & 20.80 & 22.80 & 0.01 \\
\hline
\end{tabular}

${ }^{1}$ Refering to the area of each layer and level of Figures 1 and $2 ;{ }^{2}$ Maximum resistances; ${ }^{3}$ Occurance of depths of the maximum resistances.

For clay soils the maximum value suggested for the soil mechanical resistance to penetration is 2.0 MPa, according to SECCO (2003), and even RP values greater than 2.7 and $2.1 \mathrm{MPa}$, in Red Latosol and Distroferric Red Latosol, respectively, were not sufficient to affect soybean yield. However, although the area is a Vertisol, we observed that this soil has clay loam texture, and therefore it is likely that the critical value of RP is well above $2.0 \mathrm{MPa}$, since for sandy soils can reach maximum of 6.0 MPa (TAVARES FILHO et al., 2010). Values between 2.0 and $2.5 \mathrm{MPa}$ have been indicated as the critical limits of soil resistance to penetration for most vegetables (SILVEIRA et al., 2010). ARSHAD et al. (1996) state that clay soils without revolving and without tillage operations are tolerable to RP values up to $4.0 \mathrm{MPa}$, due to the permanence and continuity of pores, biological activity more active and more stable aggregates.

Thus, assuming RP around 2.5 MPa as limiting values to the development of the root system, it appears that RP values found in the area can be restrictive for the growth of its roots. So the period in which the soil remains with high humidity is small, since the area irrigation is by furrow on alternate days, thereby the resistance of the soil may vary rapidly, increasing the levels that can be restrictive for roots growth as the soil dries. This was observed by ASSIS et al. (2009), studying a Distroferric Red Latosol with sandy clay loam texture and a Distroferric Red Nitosol with sandy clay texture, in which was observed an increase in RP of respectively $313 \%$ and $26 \%$ when soil moisture was reduced from $22 \%$ to $14 \%$. Thus, the conditions presented in some regions of the area can be considered critical for the development of roots during periods when the soil is low in humidity, which can also be confirmed by the difficulty presented in the penetration of the penetrometer in locations where the humidity was low.

We can state that soil characteristics and type of management performed contributed to alleviate problems with compression. Because, despite being an area where the soil is not revolved for more than nine years and does not have vegetation coverage in the region between the lines, the biggest pressures in the soil come from animals, carts and/or machinery traffic during the application of fertilizers or pesticides and in harvest. In addition, the soil contains clay loam texture, and being a Vertisol is common to observe processes of expansion and contraction with subsequent wetting and drying of it, which may assist in breaking of compacted layers, partially recovering the 
soil over the years (REICHERT et al., 2007). As a way of preventing compaction in Vertisol areas, we suggest greater care when driving machinery, implements, carts and animals when the soil is humid. Another suggestion would be to maintain a vegetation coverage in the area because of several advantages as: compaction energy dissipation during traffic (VASCONCELOS et al, 2012.), increased organic matter content in the soil (ROSADO et al., 2012), mineralization of nutrients during decomposition of organic matter (TORRES et al., 2008), better conservation of soil moisture (SANTOS et al., 2011) and lower variation of temperature during the day (CHABAT, 2010).

\section{CONCLUSIONS}

The soil mechanical resistance to penetration showed high variability in the surface layer.

The values of soil mechanical resistance to penetration found are considered critical to the development of the root system on the mango culture.

In areas with shorter production of mango culture, the depth of soil mechanical resistance to penetration is found in up to $0.27 \mathrm{~m}$ of depth.

\section{ACKNOWLEDGEMENTS}

The authors thank the FAPESB - Foundation for Research of the State of Bahia, for the project financial support (PPP Program) and by the scientific initiation scholarship (IC-Quotas Program) for the third and fourth authors. They thank to the SECTI - Bahia State Department of Science, Technology and Innovation and to the CNPq - National Council for Scientifc and Technological Development.

\section{REFERÊNCIAS}

AGUIAR, A.O.; FURLANI, C.E.A.; TOLEDO, A.; ZERBATO, C., ROSSINI, D. B. Compactação do solo na fileira e entrefileira de plantio de cana-de-açúcar em área de produção mecanizada. In: CONGRESSO DE INICIAÇÃO CIENTÍFICA DA UNESP, 21., 2009, São José do Rio Preto. Anais... São José do Rio Preto: UNESP, 2009. 1 CD_ROM

ASAE-American Society of Agricultural Engineers. ASAE S313.3: soil cone penetrometer. St. Joseph, 1999. 834p.

ARSHAD, M.A.; LOWERY B.; GROSSMAN B. Physical tests for monitoring soil quality. In: DORAN, J.W.; JONES, A.J. (Eds). Methods for assessing soil quality. Madison: Soil Science Society of America, 1996. p.123-141 (SSSA Special Publication, 49).

ASSIS, R. L.; LAZARINI, G. D.; LANÇAS, K. P.; CARGNELUTTI FILHO, A. Avaliação da resistência do solo à penetração em diferentes solos com a variação do teor de água. Engenharia Agrícola, Jaboticabal, v.29, n.4, p.558-568, 2009.

BONNIN, J. J; MIRÁS-CAVALOS, J. M.; LANÇAS, K. P.; GONZÁLEZ, A. P.; VIEIRA, S. R. Spatial variability of soil penetration resistance influenced by season of sampling. Bragantia, Campinas, v.69, p.163-173, 2010. Supl.

CARVALHO JÚNIOR, I.A.; FONTES, L.E.F.; COSTA, L.M. Modificações causadas pelo uso e formação de camadas compactadas e, ou, adensadas em um Latossolo Vermelho-Escuro textura média, na região do Cerrado. Revista Brasileira de Ciência do Solo, Viçosa, MG, v.22, n.3, p.505514, 1998.

CARVALHO, L.A.; NETO, V.J.M.; SILVA, L.F.; PEREIRA, J.G.; NUNES, W.A.G.A.; CHAVES, C.H.C. Resistência mecânica do solo à penetração (RMP) sob cultivo de cana-de-açúcar, no município de Rio Brilhante-MS. Revista Agrarian, Dourados, v.1, n.2, p.7-22, 2008. 
CARVALHO, G.J.; CARVALHO, M.P.; FREDDI, O.S.; MARTINS, M.V. Correlação da produtividade do feijão com a resistência à penetração do solo sob plantio direto. Revista Brasileira de Engenharia Agrícola e Ambiental, Campina Grande, v.10, p.765-771, 2006.

CHABAT, M.M. Influência dos resíduos vegetais na superfície do solo na dinâmica de evaporação da água e temperatura do solo. 2010. 92f. Dissertação (Mestrado em Ciência do Solo), Universidade Federal de Santa Maria, 2010.

COELHO, D. S.; CORTEZ, J. W.; OLSZEVSKI, N. Variabilidade espacial da resistência mecânica à penetração em Vertissolo cultivado com manga no perímetro irrigado de Mandacaru, Juazeiro, Bahia, Brasil. Revista Brasileira de Ciência do Solo, Viçosa, MG, v.36, n.3, p. 755-764, 2012.

COSTA N.D.; ARAUJO J.F.; SANTOS C.A.F; RESENDE G.M.; LIMA M.A.C. Desempenho de cultivares de cebola em cultivo orgânico e tipos de solo no Vale do São Francisco. Horticultura Brasileira, Brasília, v.26, n.4, p.476-480, 2008.

CUNHA, J. P. A. R. da; CASCAO, V. N. e REIS, E. F. dos. Compactação causada pelo tráfego de trator em diferentes manejos de solo. Acta Scientiarum Agronomy, Maringá, v.31, n.3, p. 371-375, 2009.

EMPRESA BRASILEIRA DE PESQUISA AGROPECUÁRIA - EMBRAPA. Manual de métodos de análise do solo. Rio de Janeiro: Centro Nacional de Pesquisas de Solos, 1997. 212p.

EMPRESA BRASILEIRA DE PESQUISA AGROPECUÁRIA - EMBRAPA. Sistema Brasileiro de Classificação de Solos. Centro Nacional de Pesquisas de Solos: Brasília, 2006. 370p.

FALKER. SoloStar - Manual. Porto Alegre: Falker Automação Agrícola, 2008. 51p.

FALKER. PenetroLOG PLG1020 - Medidor Eletrônico de Compactação do Solo. Disponível em: < http://www.falker.com.br/download.php>. Acessado: em 23 set. 2010.

LANDIM, P.M.B. Análise estatística de dados geológicos. São Paulo: UNESP, 1998. 226p.

MARTINS, C.A.S.; PANDOLFI, F.; PASSOS, R.R.; REIS, E.F.; CABRAL, M.B.G. Avaliação da compactação de um Latossolo Vermelho-Amarelo sob diferentes coberturas vegetais. Bioscience Journal, Uberlândia, v.26, n.1, p.79-83, 2010.

MEDEIROS, J. C.; FIGUEIREDO, G. C.; MAFRA, A. L. Portable penetrometer for agricultural soil: sensitivity test to identify critical compaction depth. Revista Brasileira de Ciência do Solo, Viçosa, MG, v.34, n.6, p. 1823-1829, 2010.

MION, R.L.; NASCIMENTO, E.M.S.; SALES, F.A.L.; SILVA, S.F.; DUARTE, J.M.L.; SOUSA, B.M. Variabilidade espacial da porosidade total, umidade e resistência do solo à penetração de um Argissolo amarelo. Semina: Ciências Agrárias, Londrina, v. 33, n. 6, p. 2057-2066, 2012.

REICHERT, J. M.; SUZUKI, L. E. A. S.; REINERT, D. J. Compactação do solo em sistemas agropecuários e florestais: identificação, efeitos, limites críticos e mitigação. Tópicos em Ciência do Solo,Viçosa, MG, v.5, p.49-134, 2007.

RIBON, A.A.; TAVARES FILHO, J. Estimativa da resistência mecânica à penetração de um latossolo vermelho sob cultura perene no norte do estado do Paraná. Revista Brasileira de Ciência do Solo, Viçosa, MG, v.32, p.1817-1825, 2008.

ROBOREDO, D.; MAIA, J.C.S.; OLIVEIRA, O.J.; ROQUE, C.G. Uso de dois penetrômetros na avaliação da resistência mecânica de um Latossolo Vermelho distrófico. Engenharia Agrícola, Jaboticabal, v.30, n.2, p.307-314, 2010.

ROSADO, T.L.; MONÇÃO, O.P.; GONTIJO, I.; PIRES, F.R.P. Efeito da cobertura vegetal nos atributos físicos de um Latossolo Amarelo cultivado com banana. Enciclopédia Biosfera, Centro Científico Conhecer, Goiânia, v.8, n.15, p. 72 1-728, 2012. 
SANTOS, T. E. M. dos; MONTENEGRO, A. A.A.; SILVA, D. D. Umidade do solo no semiárido pernambucano usando-se reflectometria no domínio do tempo (TDR). Revista Brasileira de Engenharia Agrícola e Ambiental, Campina Grande, v.15, n.7, p. 670-679, 2011.

SECCO, D. Estados de compactação de dois Latossolos sob plantio direto e suas implicações no comportamento mecânico e na produtividade de culturas. 2003. 108 f. Tese (Doutorado em Agronomia), Universidade Estadual de Santa Maria, Santa Maria, 2003.

SECCO, D.; REINERT, D. J.; REICHERT, J. M.; SILVA, V. R. da. Atributos físicos e rendimento de grãos de trigo, soja e milho em dois Latossolos compactados e escarificados. Ciência Rural, Santa Maria, v. 39, n.1, p.58-64, 2009.

SENE, M.; VEPRASKAS, M.J.; NADERMAN, G.C.; DENTON, H.P. Relationships of soil texture and structure to corne yield response to subsoiling. Soil Science Society of America Journal, Madison, v.49, p.422-427, 1985.

SILVEIRA, D. de C.; MELO FILHO, J. F. de; SACRAMENTO, J. A. A. S. do; SILVEIRA, E. C. P. Relação umidade versus resistência à penetração para um Argissolo Amarelo distrocoeso no recôncavo da Bahia. Revista Brasileira de Ciência do Solo, Viçosa, MG, v.34, n.3, p.659-667, 2010.

TAVARES FILHO, J.; BARBOSA, G. M. C; RIBON, A. A. Physical properties of dystrophic red latosol (oxisol) under different agricultural uses. Revista Brasileira de Ciência do Solo, Viçosa, MG, v.34, n.3, p.925-933, 2010.

TORRES, J. L. R.; PEREIRA, M. G.; FABIAN, A. J. Produção de fitomassa por plantas de cobertura e mineralização de seus resíduos em plantio direto. Pesquisa Agropecuária Brasileira, Brasília, v.43, n.3, p.421-428, 2008.

VASCONCELOS, R. F. B.; CANTALICE, J. R. B.; MOURA, G. B. A.; ROLIM, M. M.; MONTENEGRO, C. E. V.. Compactabilidade de um Latossolo Amarelo distrocoeso dos tabuleiros costeiros de Alagoas sob diferentes sistemas de manejo da cana-de-açúcar. Revista Brasileira de Ciência do Solo, Viçosa, MG, v. 36, n. 2, p. 537-545, 2012.

WARRICK, A.W.; NIELSEN, D.R. Spatial variability of soil physical properties in the field. In: HILLEL, D., ed. Applications of soil physics. New York: Academic Press, 1980. 